\title{
Manunggaling Kawula Gusti in Dewa Ruci Story of Cinema Wayang Performance
}

\author{
Sunardi \\ Faculty of Performing Arts, Institut Seni Indonesia Surakarta \\ Jl. Ki Hadjar Dewantara No. 19, Kentingan, Jebres, Surakarta 57126
}

\begin{abstract}
This paper aimed to explain the concept of Manunggaling Kawula Gusti in the performance of cinema wayang, Dewa Ruci story. Manunggaling Kawula Gusti is a perspective of Javanese people to express the union between humans and God. Manunggaling Kawula Gusti behavior can be carried out by humans with clean souls. The problems regarding the concept of Manunggaling Kawula Gusti are significant to be examined by the hermeneutic approach, by interpreting the values of the nature of life's journey contained in the dramatic structure of Dewa Ruci story. The results of the research showed: (1) Dewa Ruci story has a complex structure related to the nature and problems of human life; (2) Bima figure is a symbol of human beings who was able to find the essence of life through the process of inner behavior to find tirta pawitra; and (3) Manunggaling Kawula Gusti became the core concept of the union of Bima with Dewa Ruci, as well as being the goal of Bima's mystical practice. The findings of this research showed the concept of Manunggaling Kawula Gusti is believed by the Javanese community as the main concept in the arrangement of the relationship between humans and God. The concept of Manunggaling Kawula Gusti becomes divinity value which leads humans to live in harmony between the microcosm and the macrocosm. Manunggaling Kawula Gusti is characterized by the degree of human being as human being and the success of finding the essence of his life.
\end{abstract}

Keywords: Manunggaling Kawula Gusti, Dewa Ruci, human beings, the water of life

DOI: $10.7176 / \mathrm{ADS} / 83-05$

Publication date:July $31^{\text {st }} 2020$

\section{Introduction}

Wayang performances in the perspective of Javanese people are believed to be means to reveal the picture of human life. In this case, the wayang story tells the lives of the characters in achieving certain goals. One of the popular wayang stories in Java is Dewa Ruci. This story contains the journey of Bima in achieving oneness with the Creator. The point is that Dewa Ruci story is about Bima's monotheism journey to be a perfect human being.

Dewa Ruci story has a variety of versions, both the source, shape, and pattern of his work. The source of Dewa Ruci story basically refers to Serat Dewa Ruci, in which it describes Bima's journey in his search of the water of life to the level of being a human being. Dewa Ruci story can be found in a number of forms, such as songs or gancaran prose. The patterns of Dewa Ruci story have varied variations, even the title of Dewa Ruci story is also called Nawa Ruci or Bima Suci, with the work orientation of Bima figure in looking for the water of life.

Dewa Ruci story contains the mystical behavior of Bima in achieving oneness with God. Bima as the central figure was always present in the whole plot. In the initial stages, Bima intends to learn from Druna to get instructions on how to find the water of life. In the next stage, Bima went on a long journey to get his goal. At first, Bima went to the forest to get tirta pawitra, then he plunged into the ocean. Bima's journey faced an obstacle from two forest watchmen giants, his family, literary brothers, and an ocean watch dragon. In the end, Bima was able to achieve his wish by getting the gift of tirta pawitra from Dewa Ruci. The meeting between Bima and Dewa Ruci was very interesting to study because it was related to the description of religious experience in an effort to become one with God. The process of unity between man and God in Javanese perspective is stated as Manunggaling Kawula Gusti.

This means, Manunggaling Kawula Gusti becomes the core of teaching as well as the highest achievement in the mystical behavior of Javanese society. Why Manunggaling Kawula Gusti becomes the core concept of Javanese Sufism teachings needs to be done in-depth study. The meaning of Manunggaling Kawula Gusti, the process of achievement, and the figure of Bima are very worthy to be elaborated in this paper. The aim is to arouse awareness of the importance of the relationship between humans and God in living life. The unity of the macrocosm and the microcosm has a real impact on the harmonization of the inner and outer force of mankind towards the human being.

\section{Literature Review and Research Method}

To discuss the concept of Manunggaling Kawula Gusti in Dewa Ruci story, various writings were traced. In Serat Dewa Ruci Kidung (1962), Tanaya stated that the writing was the work of a Surakarta poet in the $19^{\text {th }}$ century. This article was sourced from Serat Dewa Ruci Kakawin. The main thing that has been described is about Bima's 
journey to find the water of life. Bima's struggle began with his study under the tutelage of Druna, getting directions on tirta pawitra, adventures to the forest and ocean, to his encounter with Dewa Ruci. In another article, namely Bima Suci (1979), Tanaya collected a variety of core life knowledge from various sources. This collection of knowledge is related to Dewa Ruci story. Regarding the story of Bima in searching for the water of life, it was also stated by Imam Musbikin in the book of Serat Dewa Ruci, Misteri Air Kehidupan (2010). Musbikin's study focused on mystical teachings in Serat Dewa Ruci so that the meaning and value contained therein was known. This study reveals teachings about humans, God, and Manunggaling Kawula Gusti. In essence, some of the studies carried out have not focused on the discussion of the concept of Manunggaling Kawula Gusti which become the orientation of the teachings in Dewa Ruci story of the cinema wayang performance.

The analysis was carried out by the hermeneutic method with the intention to search and find the meaning contained in the object of research in the form of the phenomenon of human life through understanding and interpretation. Basically, hermeneutic work is to find and capture the objective geist contained in the object of study. Objective geist is interpreted as the deepest meaning, or the nature of the values contained in the object of study (Schleiermacher, 1977). Ahimsa emphasized that in art, hermeneutics means explaining and revealing the meaning of art texts. What is revealed is not a causal relationship, but the understanding that lies behind the art text. A significant step in hermeneutics is interpretation, which means uncovering what is considered as being referred to by an art text which is seen as the meaning of the analyzed art text (2000: 403-404). This means that the interpretation of Dewa Ruci story in the cinema wayang performance is significant to find the concept of Manunggaling Kawula Gusti which becomes its deepest meaning.

\section{Research Results and Analysis}

The study of the concept of Manunggaling Kawula Gusti cannot be separated from its source, namely Dewa Ruci story of cinema wayang performance. To understand the contents and plot of Dewa Ruci, it is necessary to state the dramatic structure of the performance. Dramatic structure contains the main idea of the story, plot, characterization, settings, and performance works. Dramatic structures form a unified wayang play. In Dewa Ruci story of cinema wayang performance, Bima acted as the main character. The storyline focused on Bima's journey to unity with his divinity.

\subsection{Dewa Ruci Story of Cinema Wayang Performance}

Cinema wayang is a form of wayang performance by combining elements of classical wayang, namely stories and supporting instruments with cinematographic approach. This means that the classic puppets are packaged in a widescreen film work. The novelty aspects of the cinema wayang performance are: (1) the performance display with a widescreen wilm format; (2) narration and dialogue are replaced with song, sulukan, gending, and runing text; (3) the work of the story plot is composed of various sources, both literature and wayang performance.

Cinema wayang performance is created for a variety of reasons, one of which is to foster interest in young people towards wayang. Today, the younger generation's appreciation of wayang fades because the transmission patterns of the previous generation stagnate. In addition, the monotonous performance display and long duration are not in accordance with the dynamics of young people's lives. On the other hand, cinema wayang performance is intended as means of the preservation and development of Indonesian wayang. Cinema wayang is expected to be one of the wayang development models which is oriented to the progress of the times. In the industrial era 4.0, the packaging of wayang performance with widescreen film formats becomes a real necessity. In the aspect of strengthening the creative industry, the cinema wayang model becomes an alternative commodity for the creative industry that is able to have an impact on the economy of the community (Sunardi et al, 2019: 1-3).

Cinema wayang is formed from several aesthetic elements, such as: (1) wayang story; (2) wayang puppet; (3) gamelan music; (4) puppeteer; (5) pengrawit and pesindhen; (6) other performance equipments; and (7) attendance of the audience. These elements have a relationship that forms the integrity of the aesthetic wayang performances.

\subsection{Dewa Ruci Story Structure}

In general, Dewa Ruci story depicts the efforts of Bima figure in achieving the perfection of life. Basically, the story of Dewa Ruci or Bima Suci or Nawa Ruci contains mystical teachings in Javanese mysticism (Mangkunagoro, 1933: 13). Bima's efforts to lead to the perfection of life were passed through various levels. This level is called behavior or mysticism. In Dewa Ruci story, the important steps that Bima went through are: learning under tutelage of Pandita Durna; being obedient and firm in carrying out the teacher's orders; destroying Tikbrasara forest and being able to get rid of its obstacles; exorcising Dewa Bayu as a good deed; going back to learn under the tutelage of Durna or not despairing to ask; getting rid of and abandoning his brothers who hindered the goal; plunging into the Minangkalbu ocean; killing the Dragon Nemburnawa or worldly lust; being surrendered sincerely to God's power; meeting Dewa Ruci to receive the light of his guidance; being manunggal and having dialogue to receive the water of life (Mulyono, 1979: 61; Tanaya, 1979: 1-24; Mangkunagoro, 1933: 23-24).

To understand the journey of Bima to find the water of life can be traced through the dramatic structure of 
the story as follows.

1) Prologue, telling of Bima's childhood, starting from the birth of a wrap (placenta), the wrap was exorcised by Gajahsena, Bima was being apart from the wrap, Gajahsena merged into Bima's body, Bima's adult life, and Bima wanted to learn under the tutelage of Durna.

2) Scene of Astina country, telling the story of Bima studying under the tutelage of Durna in the country of Astina to look for the water of life, Bima obtained orders to search Mount Reksamuka.

3) Mount Reksamuka scene, telling of two giants named Rukmuka and Rukmakala angry with Bima. There was a fight until the two giants turned into Dewa Bayu (a god). He was happy because Bima had returned his form as a god. Bayu suggested that Bima met his teacher again. Bima meditated and was instructed by Durna to go to the ocean.

4) The Amarta country scene, telling the story of Kunti, Pandawa, and Kresna being restless for the departure of Bima. Bima's arrival surprised them. Bima asked farewell to his mother and siblings, but was not allowed. Bima was desperate to obey his wishes.

5) Travel scene, telling the story of Bima's journey confronted by close relatives (sometimes Bayu), but Bima was able to overcome obstacles to rush to the ocean.

6) Samodera scene, telling about the doubts of Bima's heart to plunge into the ocean. There were three birds in the trees, they gave enthusiasm so that Bima did not hesitate to plunge into the ocean. Bima immediately plunged into the ocean.

7) Ocean scene, telling about Bima fighting against Naga Nemburnawa. Bima was able to kill the dragon and lost consciousness. Bima met Dewa Ruci. Bima got knowledge about the origin and purpose of life, Bima got the water of life. Bima was able to get out from the ocean.

8) Sokalima scene, telling the tension between Durna and Pandavas. Bima's presence made the Pandavas, Kresna and Kurawa happy. Bima obtained the water of life at the behest of Durna.

\subsection{Bima as A Symbol of Human Being}

In order to understand the concept of Manunggaling Kawusti Gusti in Dewa Ruci story, it is necessary to examine the identity of Bima character. In wayang, Bima character has a special position compared to other figures. The specialty of Bima lies in several things, such as: (1) origin; (2) figure shape (anatomy); (3) speech acts and voice color; (4) life principles; and others. Bima's specificity gives a picture of a man who is brave, straightforward, and has extraordinary abilities.

Bima is the son of Kunthi and Pandhu in the kingdom of Astina. Bima was born from Kunthi's womb after bringing Dewa Bayu to give offspring to Pandhu. This means that the origin of Bima is full of mystery, because he was born from the aura of Dewa Bayu. He also had the character of a god like Bayu.

In wayang performance, the figure of Bima is depicted as a man who is brave and has a big tall body. When born, he was not like a human baby, but in the form of a placenta (wrap). Bima placenta had been placed in the forest so it could be torn by wild animals. After all, Dewa Bayu ordered Gajahsena to break the wrap. When the wrap was broken, Gajahsena's body merged with Bima to increase the power of the mighty.

The specificity of Bima can also be seen from the speech acts and the color of his voice. He became a figure who always used the language of ngoko to anyone such as fellow knights, punakawan, kings, brahmins, and the gods. There was only one character who changed Bima's speech act, namely Dewa Ruci. Bima applied polite Javanese language (krama) to Dewa Ruci because he was considered as the highest figure who deserved to be respected physically and mentally. In addition, the voice color of Bima character has a specificity, namely large, echoing, and blaring in accordance with the anatomy of his body.

Bima had a certain principle of life and was non-negotiable. He would uphold his words and actions in harmony. If it was a yes, then he said yes. When it was a no then he would say no. (If he was able to do something, he must do it. If he was not able to do it, he would not do it). Even the most famous philosophy of warfare is that Bima would not surrender or lose; getting lose if he died. Bima's philosophy of life is reflected in his efforts to find the water of life or find his identity in Dewa Ruci story.

Bima became a symbol of a figure who tried to find his identity through a mystical journey. To become a perfect human being, as a human being, it requires serious efforts through his inner journey. This process can be likened to the individuation process (Dahler and Chandra, 1984: 128) or the process of self-identification (Peursen, 1978: 68). The process towards Bima's self-identification was carried out in several stages or behavior. Ciptoprawiro (1986: 71) refers to physical behavior, mental behavior, manah behavior, and taste behavior. In a general sense referred to as the stage of shari'a, tariqa, essence, and ma'rifa (Solichin, 2011: 104). These four stages were passed by Bima as a significant process to find his identity.

The shari'a stage is the earliest journey to perfection, marked by human efforts to carry out the physical and outward practices of religious law. This practice concerns the arrangement of human relations with God, human relations with other humans, and human relations with the universe. Bima's mystical journey at this stage was described when he was obedient and respectful to his teacher, Resi Durna. Bima's obedience to the teacher was 
shown when he carried out the order to look for tirta perwita to the Mount Reksamuka.

Mulder stated that behavior (worship) or tariqa functions as a stage of human journey to meet the Creator. The indication appears in the awareness of behavior and physical practices is more advanced, deeper, and more increased (1983: 24). This stage is more concerned with the relationship between humans and God rather than human relationships with humans or with nature, and therefore all human life practices lead to the process of surrender to the Almighty. Bima's journey in the practice of the tariqa is shown by his sincerity in learning under the tutelage of Durna. When the first trip he did not find the water of life, Bima returned to Durna to ask for directions again. Bima respected the teacher so much that he did not despair of making the second journey to the ocean. Bima gave his body and soul to Durna to reach the water of life. This is the path of the tariqa, an attitude of deeply surrender for Bima who takes himself to the next stage, namely the stage of nature.

At the stage of nature, it is interpreted as manah behavior (worship of the soul) that is the perfect journey to divinity. This mystical practice is obtained by knowing God through oneself by way of dhikr or prayer. The practice is done solely because of God. Mulder refers to life born as abandoned to live his inner life (1983: 24). This stage is marked by the unveiling of the veil that prevents humans from becoming one with God, namely lust. When the shortest veil man senses that he and the universe do not exist, all that is seen is "What Exists". Mulyono said that this stage is a state of death in life and life in death, so that in a state between conscious and unconscious a real flame appears called Nur Illahi (1978: 126). In Dewa Ruci story, it is shown when Bima recognized God through himself, experienced and witnessed empty nature, saw true light or pancamaya, saw four colors of light, and saw pramana.

In the next process, Bima took a sense of action (worship) or the stage of ma'rifa, which is interpreted as a journey to the highest perfect human being. In Sufism, ma'rifa implies knowing directly about God with the truth of His guidance, including the essence and nature (Musbikin, 2010: 221). The attainment of the ma'rifa is a continuation of the level of the tariqa, that is, when the curtain is opened, so that humans will feel that he and nature really do not exist, there is only "What Exists". Here the Essence of God has penetrated into one with humans, where this situation can not be explained (tan kena kinaya ngapa), which felt only beautiful and peaceful. The situation experienced by Bima at this stage was that he felt the state of himself with God like water with waves, pleasure and peace, everything that was desired was achieved, life and death were no different. In the mystical view of kejawen, this is said to be Manunggaling Kawula Gusti, namely the union between humans and the Highest Essence.

Bima's ability transcended the stages of Shari'a, tariqa, essence, until reaching the ma'rifa which gave a clue that he was a perfect human being or was said to be a human being. A perfect human being in the sense of being able to find his true self, find a harmonious union between himself and the Essence of God known as Manunggaling Kawula Gusti occassion. .

\subsection{Manunggaling Kawula Gusti in Dewa Ruci Story}

Manunggaling Kawula Gusti is believed to be a way of life for Javanese to find an understanding of the origin and purpose of human life. Manunggaling Kawula Gusti is not only a teaching but a real experience experienced by humans who have experienced it. The experience of union with God, which is known as fusion, integrity, unity, or oneness (Musbikin, 2010: 38). This experience brings people to the highest pleasure because they feel together with the Creator. In the Javanese mind, unification with God is often referred to as Manunggaling Kawula Gusti, or by the equivalent of the word Jumbuhing Kawula Gusti. Here there are two poles that are interlocked, two subjects that are fused, namely man and God.

The union between humans and God cannot be described auditively or visually, but can only be felt by those who experience it. Because God tan kena kinaya ngapa, and threfore the inner encounter between man and God in nature is indefinable. Manunggaling Kawula Gusti exists in the inner world of Javanese people, which has implications for achieving the standard of living as an ideal human being. Sutrisno et al (2009: 95) explain that Manunggaling Kawula Gusti as the principle of divine life in humans, one of the deepest realities as a condition of perfection.

Manunggaling Kawula Gusti can be represented in Dewa Ruci story of cinema wayang performance. In essence, this story tells about the mystical journey of Bima in achieving oneness with the Creator. Mangkunegoro (1933) states that wayang story teaches the practice of meditation for Javanese people. One example is Dewa Ruci story. Semadi behavior is portrayed with visual and auditive narrative through Dewa Ruci story of wayang performance. In Dewa Ruci story of cinema wayang performance, semadi behavior was portrayed through Bima's journey to find tirta pawitra. To achieve tirta pawitra, it took oneness with the Creator or known as Manunggaling Kawula Gusti.

There were four stages that Bima went through in achieving oneness, namely the stages of Shari'a, tariqa, essence, and ma'rifa. This stage is reflected in Dewa Ruci story of cinema wayang performance. At the stage of Shari'a, it was implemented through Bima's strong desire to learn under the tutelage of Durna in Astina country. Bima believed that Durna was a teacher who had high knowledge so that it was worthy of his choice to get the 
water of life. This stage is reflected in sulukan pethetan nem wantah with the following lines:

(Translation: King Duryudana said smoothly, O Bima, I welcome you, Bima immediately approached Durna, Bima was embraced, O my son, find immediately, the holy water of life, as a means of revealing the science of the perfection of life)

(Translation: Teacher, I beg you for instructions, where the holy water is, in the cave on Mount Candramuka, dismantle until you find it, Bima moved, immediately saluted to say goodbye).

The snippet of the poem and gerongan above gives a guidance about the journey of Bima figure to learn under the tutelage of Durna. As a student, Bima acted respectfully and followed the instructions given by his teacher. In this scene, it is an indication of Bima's behavior in carrying out physical and outward practices of religious law. Bima's behavior also showed the human relations with other humans, namely with the teacher and the king. In this cinema wayang performance, the stage of Bima's journey to undergo Shari'a behavior is narrated through poem of sulukan and gerongan, accompaniment of gending, and movements of Bima characters in scenes in the country of Astina.

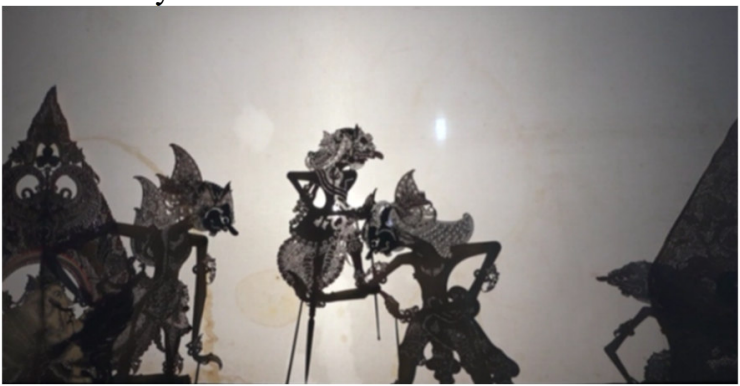

Figure 1. Bima learned under the tutelage of Durna

in Astina country (Photo: Sunardi, 2020)

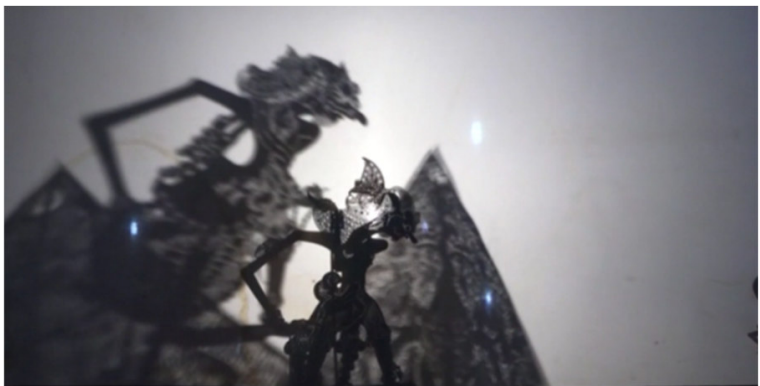

Figure 2. Bima requested a second guidance to Durna (Photo: Sunardi, 2020)

In the next stage, tariqa was indicated from the improvement of Bima's practice to totally follow the instructions of his teacher, Resi Durna. Here, it has been seen an improvement in the order of human relations with God by Bima. In Dewa Ruci story of cinema wayang performance, the representation of tariqa stage was listened to in the scene when Bima returned to his teacher to ask for instructions on the existence of tirta pawitra after his efforts to find the water of life in Mount Reksamuka by combing the place and defeating two cave watchmen, and Bima's attempt to ask Durna for the second time. Representation of this stage can be assessed through poem pathetan sanga wantah, ada-ada greget saut slendro sanga, and palaran pangkur as follows.

(Translation: Bima pondered in his heart, for failing to obey his will, but not discouraged, prayed to God, may be brought closer to grace, and kept away from misfortune)

(Translation: immediately in a moment of silence, Raden Bratasena, was granted for his request, clearly seen his presence, heard in the words of his teacher)

(Translation: my Mighty son, know this if you are trying, really follow the teacher's instructions, now listen, truly the real place, the holy water of life, is at the center of the ocean).

The poem, which was packed in Bima scene meeting Batara Bayu in Reksamuka and Bima scene meeting Durna in cinema wayang performance of Dewa Ruci, gave an understanding of the stages of the tariqa that Bima successfully performed. This stage of reflection was carried out by Bima by exorcising Bayu from the gods temptation and Bima's resolve to return to ask his teacher for instructions on the existence of holy water. The main characteristic of the tariqa stage lies in increasing the depth of the inner human effort to practice religious teachings. What Bima did by exorcising Bayu and believed his teacher wholeheartedly shows an increase in the inner connection of humans with God. Bima's practice was based on surrender to God to get what he aspired.

The tariqa behavior of Bima was also shown in its power to remove obstacles, especially from family and siblings. Bima believed his strength surrenders to God's will by totally following the teacher's instructions. The obstacles of the Pandava family and siblings (kadang bayu) were depicted in the scenes of the country of Amarta and Kadang Bayu deterrence implied in the poem as follows.

(Translation: my son who is mighty, your presence brings happiness, you must always remember, Kurawa's crime, well I beg you to say goodbye to your mother, find a way to learn, plunge into the ocean).

(Translation

Anoman : Stop Bima, where are you going?,

Bratasena : Looking for the water of life in the ocean,

Anoman : Please, don't do that, my brother. Come back, you will die, be eaten by sea animals,

Bratasena : Look at everything,

Anoman : Rather than dying in the ocean, it is better to die together on this land).

(Translation: 
Setubanda: I'm your older brother, don't continue on your journey, if you don't come back you will surely die,

Bratasena : You elephant! a barbarous barrier.

The practice of tariqa is manifested as the worship of the mind or the practice of the mind leading to human consciousness to set aside various obstacles, both family and others. The purpose of finding the water of life became the focus of Bima's behavior and journey so that he left his mother and sibling (Pandava), even ignoring his siblings (kadang bayu). The success of Bima beyond this stage guided his heart and behavior in the next stage, namely the essence stage.

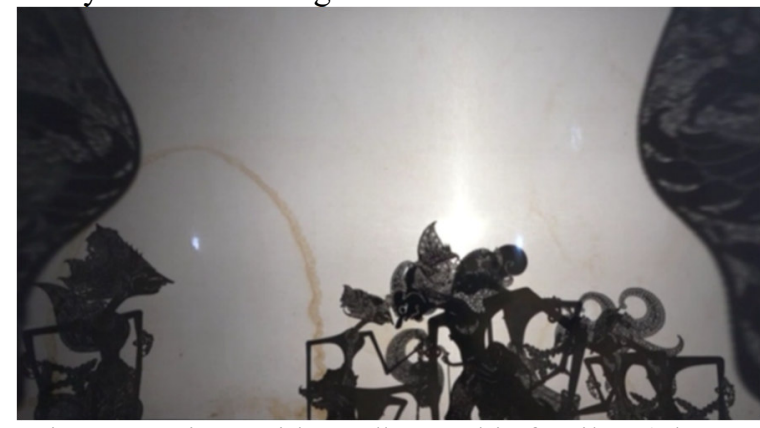

Figure 3. Bima said goodbye to his family (Photo: Sunardi, 2020)

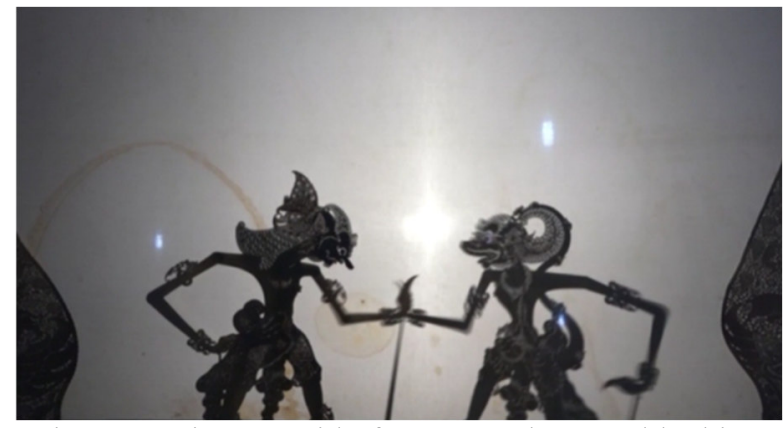

Figure 4. Bima got rid of Anoman that was blocking his way (Photo: Sunardi, 2020)

At the essence stage, the process of uniting oneself with the Creator is marked by the opening of a barrier between the transcendent world and the immanent. The barrier to unity is lust in human beings, so that human ability is needed to curb lust of anger, aluamah, mutmainah, and supiah. At the stage of worship of the soul or manah behavior marked by the occurrence of human consciousness leaving the outer world to the inner world. In the cinema wayang performance, Dewa Ruci was shown through Bima's meeting with Dewa Ruci. This means, Bima knew God through himself. This stage is represented in the scene of Bima meeting Dewa Ruci at the bottom of the ocean, as ordered through the following lines of poem.

(Translation:

Bratasena : This is means of knowing knowledge, analyzing the perfection of life,

Dewa Ruci : Bima come here, get inside my body, I will describe it,

Bratasena : My lord is only as little as a finger, I have a big body, then how can I get into your body?

Dewa Ruci : Through my right ear.

(Translation:

Dewa Ruci : Bratasena, what did you see?

Bratasena : The empty state of virtual light, no shadow, no vegetation, no moonlight, feeling of being at home, happy, peaceful, what is this place?

Dewa Ruci : The unconscious world is like a dream, O Bima, remember).

(Translation:

Dewa Ruci : Bratasena is indeed perfection, has possessed you, four manifestations,

bound in white, red black and yellow, black lust of wrath, red is anger, yellow is closer to desire, white is special for the sincerity of the soul, know this.) .

In the scene of Bima meeting with Dewa Ruci as reflected in the poem above, it indicates the attainment of human mystical practices, namely knowing God through himself, watching the Pancamaya, seeing the four colors, and knowing the description of the knowledge of sastrajendra. This stage shows the ability of humans to recognize and unite with God, Jumbuhing Kawula Gusti through the process of death of mati sajroning urip, urip sajroning mati until there is a fusion of loro-loroning atunggal, two in unity, namely human and God.

The final mystic stage of Bima is the ma'rifa, that is, the condition when humans know God to the best of His guidance. In Dewa Ruci story of cinema wayang performance, it was described when Bima realized his unity with the Creator. This unification has an impact on the feeling of pleasure and beauty that can not be explained (tan kaya kinaya why). This achievement is called Manunggaling Kawula Gusti or warangka manjing suspicious, suspicious manjing warangka. The mystical peak of Bima is represented in the poem as follows.

(Translation:

Dewa Ruci : Bima, please go home soon,

Bratasena : I'm happy here, it feels good and useful,

Dewa Ruci : True favors and benefits, being in the world, don't go wrong, look in the sky,

Bratasena : My shadow is seen,

Dewa Ruci : If you see it up to three times then beware.

Dewa Ruci : Bima look back, I immediately make a hair bun to your hair, called gelung Minangkara, low in front, 
high behind,

Werkudara : What does this mean?

Dewa Ruci : You have succeeded, the union of God with humans, return to the world, carry out yourself as a human).

Bima's journey to achieve union with God could be realized perfectly through a long process. Manunggaling Kawula Gusti became the orientation of Javanese mystical behavior in an effort to become a perfect human being. This means that Manunggaling Kawula Gusti is a benchmark for achieving harmony in the inner world of man and harmony in the universe.

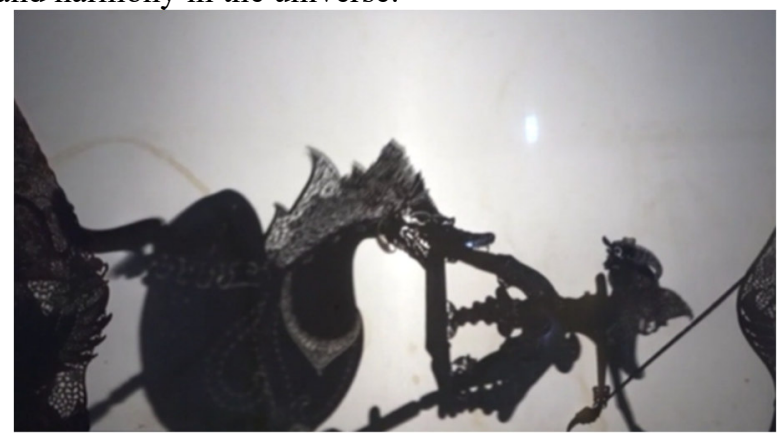

Figure 5. Bima fought Nemburnawa (Photo: Sunardi, 2020)

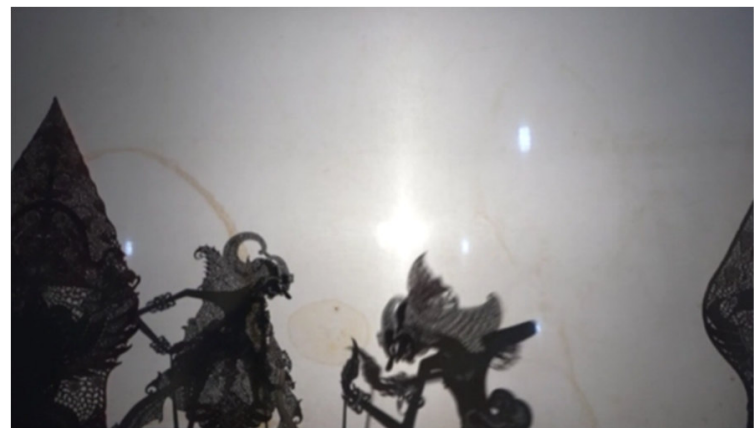

Figure 6. Bima met Dewa Ruci (Photo: Sunardi, 2020)

\section{Conclusion}

Dewa Ruci story of cinema wayang performance represents the concept of Manunggaling Kawula Gusti. Bima's attempt to find the water of life is described as Bima's meeting with Dewa Ruci on the instructions of Durna's teacher. In this case, there is a significant relationship, namely Bima with Durna, and Bima with Dewa Ruci. The relationship between Bima and Durna in the framework of the process of finding the water of life. The relationship between Bima and Dewa Ruci is related to the achievement of oneness, or Manunggaling Kawula Gusti.

Manunggaling Kawula Gusti is interpreted as a human inner experience to meet God. The path taken by selfcontrol to the stage as a perfect human being. The process of Manunggaling Kawust Gusti in Bima was carried out with four stages, namely syari'a, tariqa, essence, and ma'rifa. Each stage shows the level of human inner depth to meet or unite with the Creator.

The mandate that can be drawn from the experience of Manunggaling Gusti is the hard effort and willingness of the human heart to achieve harmony between the microcosm and the macrocosm, namely the harmony of the inner world of man and the harmony of the universe. The peak of Manunggaling Kawula Gusti is the cosmic order that brings human consciousness to the level of life that is happy both physically and mentally. Manunggaling Kawula Gusti becomes a key concept for the management of human relations with humans, with nature, and with God.

\section{References}

Ahimsa-Putra, Hedy Shri Ed). (2000), Ketika Orang Jawa Nyeni, Yogyakarta: Galang Press.

Ciptoprawiro, Abdullah. (1986), Filsafat Jawa, Jakarta: Balai Pustaka.

Dahler, Franz dan Julius Chandra. (1984), Asal dan Tujuan Manusia (Teori Evoluasi), Yogyakarta: Kanisius.

Mangkunegoro VII, KGPAA. (1933), "On the Wayang Kulit (Purwa) and Its Symbolic and Mystical Elements", Terjemahan Clair Holt Original Text Published in Jawa, Vol. XIII.

Mulder, Niels. (1983), Kebatinan dan Hidup Sehari-hari Orang Jawa Kelangsungan dan Perubahan Kulturil, Jakarta: Gramedia.

Mulyono, Sri. (1978), Tripama, Watak Satria dan Sastra Jendra, Jakarta: Gunung Agung.

Musbikin, Imam. (2010), Serat Dewa Ruci (Misteri Air Kehidupan), Jogjakarta: Diva Press.

Schleichermaker, F.D.E. (1977), Hermeneutics: The Handwritten Manuscripts, (Ed. Heinz Kimmerle, Terjemahan James Duke dan Jack Forstman. Montana: Scholars Press

Solichin. (2011), Filsafat Wayang Intangible Heritage of Humanity, Jakarta: Senawangi.

Sunardi dkk. (2019), Wayang Sinema Lakon Dewa Ruci Model Pengembangan Wayang Indonesia, Surakarta: ISI Press.

Sutrisno, Slamet dkk. (2009), Filsafat Wayang, Jakarta: Sena Wangi.

Tanaya, R. (1962), Serat Dewa Ruci Kidung, Surakarta: Toko Buku Pelajar

Tanaya, R. (1979), Bima Suci, Jakarta: Balai Pustaka. 